\title{
Healthcare waste management in Germany
}

\author{
Dorothea Hansen', Ulrich Mikloweit ${ }^{2}$, Birgit Ross ${ }^{3}$, Walter Popp ${ }^{3}$ \\ 1. Central Hospital Hygiene, University Clinics Köln, Germany \\ 2. Occupational Safety Unit, University Clinics Essen, Germany \\ 3. Hospital Hygiene Unit, University Clinics Essen, Germany
}

doi: 10.3396/IJIC.v10i1.006.14

\begin{abstract}
Disposal of healthcare waste may pose complex problems because of the broad range of its composition. Household waste has to be managed as well as infectious and hazardous materials, parts of human origin from pathologies or operating theatres and recyclable waste. Occupational safety, legal and economic aspects have to be considered. German good practice guidelines to define, classify and treat medical waste are presented.
\end{abstract}

Keywords: Medical Waste Disposal and legislation and jurisprudence and organization and administration

\section{Introduction}

Waste management at healthcare facilities such as hospitals, physician's offices, dental practices, blood banks, laboratories and at home health-care may pose a challenge to the facility. Improperly managed healthcare waste not only can pose risks for patients, visitors, healthcare workers, waste handlers, the community and environment but also can produce considerable costs. Disposal of healthcare waste has not only to respect statutory rules, occupational safety and environment protection but also work flows of healthcare facility and economical demands.

\section{Legislative and regulatory aspects of healthcare waste}

Waste management in Germany has to respect numerous laws and prescriptions. The principle law is the "Closed Substance Cycle Waste Management Act" which regulates prevention, recycling, reuse and disposition of waste. ${ }^{1}$ In addition, adherence to infection control and safety regulations is necessary. ${ }^{2}$ Hospitals are obliged to denominate someone who is responsible for proper waste disposal. Depending on the size of the facility, the person should be released from other works. The person is responsible for adherence to occupational safety and legal requirements. Segregation and proper waste disposal has to be incorporated in facility's quality management. Correct disposal of hazardous waste has to be proofed towards authorities. ${ }^{3}$ Transport of hazardous waste has to attend to the Dangerous Goods Regulation. ${ }^{4}$ Incineration of waste has to respect Federal Control of Pollution Act. $^{5}$

\section{Corresponding author}

Dorothea Hansen

University Clinics Köln, Central Hospital Hygiene, Germany

Email: Dorothea.Hansen@uk-koeln.de 


\section{Composition and classification of healthcare waste}

Depending on the kind of healthcare facility, waste can be composed of a broad range of materials including infectious, hazardous, radioactive and general waste. Waste is classified according to the European Waste
Catalogue and Hazardous Waste List. ${ }^{6}$ Classification considers origin, character and composition of waste. Hazardous wastes are hallmarked. A German working group on healthcare waste management has published a guideline which can be consulted when legal and

Table I: Examples of healthcare waste ${ }^{7}$

\begin{tabular}{|c|c|c|c|c|}
\hline Category & Examples & Origin & Collection & Disposal \\
\hline Sharps & $\begin{array}{l}\text { Needles, scalpels, } \\
\text { lancets, infusion sets, } \\
\text { broken vials and } \\
\text { ampoules }\end{array}$ & $\begin{array}{l}\text { Medical ward, } \\
\text { physician's offices, } \\
\text { operating theatre, } \\
\text { laboratory, home } \\
\text { healthcare }\end{array}$ & $\begin{array}{l}\text { Immediate collection } \\
\text { at the point of origin } \\
\text { in puncture resistant, } \\
\text { leakproof and } \\
\text { closable containers }\end{array}$ & $\begin{array}{l}\text { Tightly closed } \\
\text { together with } \\
\text { general waste }\end{array}$ \\
\hline Anatomical waste & $\begin{array}{l}\text { Filled blood bottles, } \\
\text { body parts, organs }\end{array}$ & Operating theatre & $\begin{array}{l}\text { At the point of origin } \\
\text { in leak proof and } \\
\text { closable container, } \\
\text { refrigerated or frozen } \\
\text { storage necessary }\end{array}$ & $\begin{array}{l}\text { In authorized } \\
\text { incineration } \\
\text { plants }\end{array}$ \\
\hline Infectious waste & $\begin{array}{l}\text { Waste containing } \\
\text { pathogens which can } \\
\text { be disseminated in } \\
\text { the environment and } \\
\text { pose infectious risk } \\
\text { to population }\end{array}$ & $\begin{array}{l}\text { Departments of } \\
\text { infectious diseases, } \\
\text { dialysis, operating } \\
\text { theatre, laboratory }\end{array}$ & $\begin{array}{l}\text { Immediate collection } \\
\text { at the point of } \\
\text { origin in proofed } \\
\text { containers, flagged } \\
\text { with biohazard } \\
\text { symbol }\end{array}$ & $\begin{array}{l}\text { Transported } \\
\text { by authorized } \\
\text { companies } \\
\text { to authorized } \\
\text { incineration } \\
\text { plants }\end{array}$ \\
\hline $\begin{array}{l}\text { Waste produced } \\
\text { during care } \\
\text { or treatment } \\
\text { without particular } \\
\text { requirements } \\
\text { on disposal }\end{array}$ & $\begin{array}{l}\text { Bandages, casts, } \\
\text { swabs, diapers }\end{array}$ & $\begin{array}{l}\text { All medical wards, } \\
\text { all medical practices }\end{array}$ & & $\begin{array}{l}\text { Can be added } \\
\text { to domestic waste } \\
\text { if municipal } \\
\text { regulations allow }\end{array}$ \\
\hline $\begin{array}{l}\text { Amalgam from } \\
\text { dentistry }\end{array}$ & $\begin{array}{l}\text { Content of amalgam } \\
\text { separator, extracted } \\
\text { teeth with amalgam } \\
\text { filling }\end{array}$ & Dental surgery & Separate collection & $\begin{array}{l}\text { Recycling by } \\
\text { producer or } \\
\text { distributor }\end{array}$ \\
\hline Chemicals & $\begin{array}{l}\text { Acids, bases, } \\
\text { dissolvents, } \\
\text { halogenated solvents, } \\
\text { disinfectants, fixing } \\
\text { baths }\end{array}$ & & $\begin{array}{l}\text { Separate collection } \\
\text { in leak-proof } \\
\text { containers, flagged } \\
\text { according to } \\
\text { hazardous properties } \\
\text { of chemical content }\end{array}$ & $\begin{array}{l}\text { Specialized waste } \\
\text { management } \\
\text { company }\end{array}$ \\
\hline Cytostatic drugs & $\begin{array}{l}\text { Not completely } \\
\text { evacuated original } \\
\text { applications, expired } \\
\text { drugs, filled syringes }\end{array}$ & $\begin{array}{l}\text { Medical wards and } \\
\text { physician's offices }\end{array}$ & $\begin{array}{l}\text { Separate collection } \\
\text { at the point of } \\
\text { origin in proofed } \\
\text { containers, flagged } \\
\text { with danger } \\
\text { symbol }\end{array}$ & $\begin{array}{l}\text { Transported } \\
\text { by authorized } \\
\text { companies } \\
\text { to authorized } \\
\text { incineration } \\
\text { plants }\end{array}$ \\
\hline
\end{tabular}


hygienic demands must be implemented in standards for segregation, packaging, labelling, storage and transportation of waste in an individual healthcare facility. ${ }^{7}$ Examples of wastes are listed in table I.

\section{General Waste}

Between $75 \%$ and $90 \%$ of waste generated in healthcare facilities is comparable to domestic waste. ${ }^{8-10}$ This waste is contaminated neither by body fluids and secretions nor by chemicals and does not contain sharps. Examples are filter bags, fruit bowls, sweepings, content of ashtrays, paper, glass or package. Demands made on disposal of this fraction do not differ from those out of healthcare facilities. According to the order on the disposal of waste from packaging costs of recycling are included in purchase prices of packages. ${ }^{11}$ Therefore beverage bottles, plastic packing material, paperboard containers and other packages as well as newspapers and magazines can be recycled (Fig 1). There also exists a recovery technique for leftovers and green waste. Waste which cannot be recycled is combusted by municipal solid waste incineration. Separation of waste has to be undertaken at the point of origin. Reusable bins have to be cleaned and disinfected regularly. ${ }^{12}$

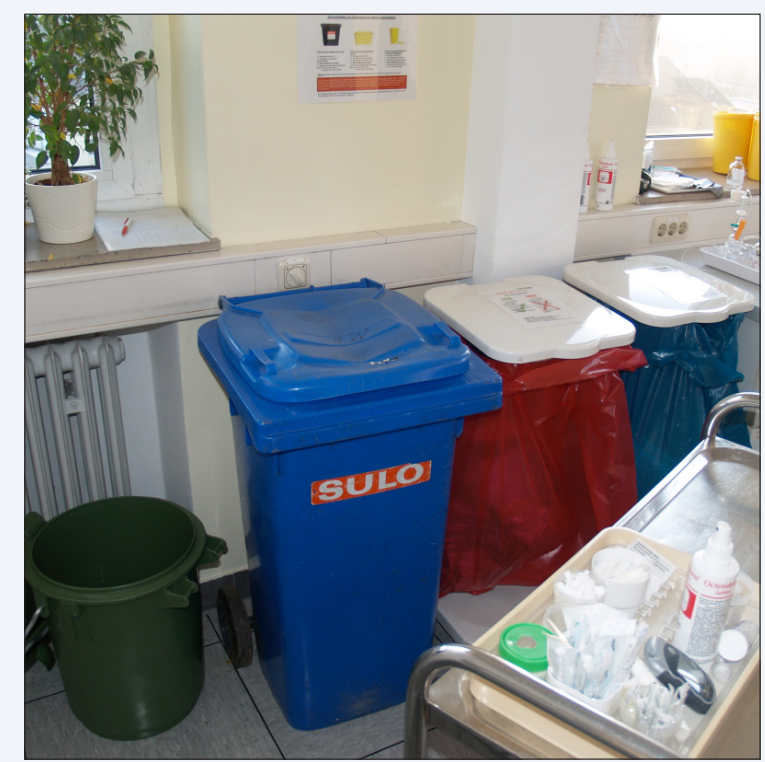

Figure 1. Different coloured bins and sacs for waste separation at the point of origin

\section{Sharps}

Sharps (needles, scalpels, broken glass, knives, infusion sets) can cause cuts and puncture wounds if handled improperly. Person at risk are healthcare workers, workers in support services such as cleaners, workers transporting waste and workers in wastemanagement facilities. To prevent harm, sharps have to be collected in puncture-resistant, leak-proof and lockable boxes. Boxes of different sizes which comply with these requirements are commercially available (Fig 2). Attention should be paid not to overfill before closure. Closed sharps boxes can be disposed together with non hazardous waste if municipal regulations allow.

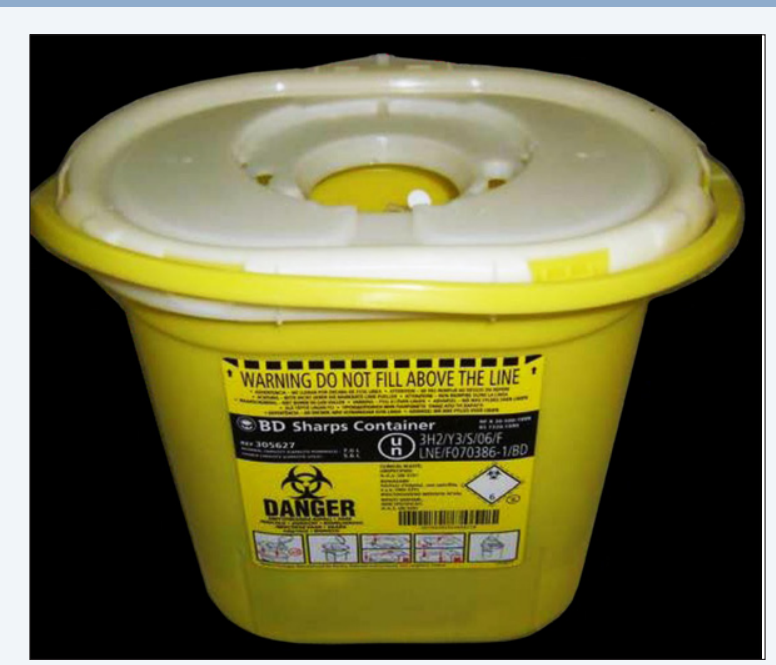

Figure 2. Commercially available boxes to collect sharps

\section{Hazardous infectious waste}

Hazardous infectious waste is contaminated with pathogens which can be disseminated and cause serious diseases if waste is thrown away sharing usual public waste disposition. Classification considers contagiousity, tenacity, mode of transmission, extent of contamination and severity of infectious disease. Examples are listed in table II. Hazardous infectious waste has to be collected in special proofed containers and labelled by the biohazard symbol. It has to be disposed by authorized companies and combusted in a hazardous waste incinerator. Microbial cultures have to be inactivated before disposal. After inactivation they can be added to domestic waste. 
Table II. Examples of infectious disease which can generate hazardous infectious waste

\begin{tabular}{|c|c|c|}
\hline Infectious disease & Mode of transmission & Infectious body fluids \\
\hline HIV & Parenteral & Blood \\
\hline Hepatis B, C & Parental & Blood \\
\hline Cholera & Contact, smear infection & Faeces, vomit \\
\hline Dysentery (bacillary, amoebic) & Contact, smear infection & Faeces \\
\hline Haemolytic-uremic syndrome & Contact, smear infection & Faeces \\
\hline Typhoid fever, paratyphoid fever & Contact, smear infection & faeces, urine, bile, blood \\
\hline Tuberculosis & Aerogen/droplet, smear infection & Sputum, urine, faeces \\
\hline Meningitis & Aerogen/droplet, smear infection & Sputum, respiratory secretions \\
\hline Brucellosis & Aerogen/droplet, smear infection & Blood \\
\hline Diphtheria & Aerogen/droplet, smear infection & $\begin{array}{l}\text { Sputum, respiratory secretions, } \\
\text { ichors }\end{array}$ \\
\hline Leprosy & Aerogen/droplet, smear infection & Nasal secretions, ichors \\
\hline Anthrax & Aerogen/droplet, smear infection & $\begin{array}{l}\text { Sputum, respiratory secretions, } \\
\text { ichors }\end{array}$ \\
\hline Plague & Aerogen/droplet, smear infection & $\begin{array}{l}\text { Sputum, respiratory secretions, } \\
\text { ichors }\end{array}$ \\
\hline Variola & Aerogen/droplet, smear infection & $\begin{array}{l}\text { Respiratory secretions, secretions } \\
\text { of pustules }\end{array}$ \\
\hline Poliomyelitis & Aerogen/droplet, smear infection & $\begin{array}{l}\text { Sputum, respiratory secretions, } \\
\text { faeces }\end{array}$ \\
\hline Rabies & Aerogen/droplet, smear infection & Sputum, respiratory secretions \\
\hline Hemorrhagic fever & Aerogen/droplet, smear infection & $\begin{array}{l}\text { Blood, sputum, respiratory } \\
\text { secretions, ichors, urine }\end{array}$ \\
\hline
\end{tabular}

\section{Waste produced during care or treatment} without particular requirements on disposal

Waste which is contaminated with blood, body fluids and secrets or excretes but which does not contain pathogens causing a disease (Table II) can be disposed as domestic waste if municipal regulations allow. Examples are bandages, casts, contaminated medical disposables, gloves, swabs etc. Collection, storage and transportation have to avoid contamination of the healthcare facility and to hold harm off patients, healthcare workers and waste handlers. If major amounts of body fluids or secrets are discharged, absorbing materials have to be added to prevent accidental release during transport.

\section{Anatomical waste}

Collection of anatomical waste such as human organs, body parts or unused blood products has to respect ethical standards. Especially proofed and labelled containers are needed which must be kept cool if storage is necessary. Combustion in a hazardous waste incinerator is performed.

\section{Hazardous chemical waste}

Not only in large hospitals with intensive research and laboratory activities chemical waste may occur. Chemical waste can be hazardous because of toxic, corrosive, flammable, explosive or oxidizing properties. Examples are photographic fixing and 
developing solutions, laboratory chemicals, solvents, spent disinfectants, fixatives, formalin, cytostatics or material with high heavy metal content. Liquid chemical waste should not be mixed and should not be spilled down the drain. It should be collected in leak proof containers which have to be clearly labelled. When possible, chemicals should be returned to the suppliers and metals (e. g. silver from photo chemicals or mercury from dentistry) should be recycled.

\section{Demands on collection, storage and transportation of healthcare waste}

Audits of healthcare waste management and storage areas have shown different problems and demands have been concluded from them: ${ }^{12-14}$

- Collection and transportation of waste has to attend to safety provisions for workers.

- Contamination of hospital environment has to be prevented.

- Appropriate protective clothing, at least solid puncture-proof gloves have to be provided to employees who are charged with the collection and transport of waste.

- Non hazardous waste produced during care or treatment of patients has to be collected in tear proof bags or barrels.

- To avoid contamination of the outer surface of bag or container during collection, pedal bin containers or foot controlled folding mechanisms to fix bags should be used.

- Waste should not be transferred or re-sorted.

- Segregation of waste at the point of production.

- Waste bags should not be thrown or dragged across the floor for transport. Carts for transporting waste can be used. They should have no sharp edges or corners that could lead to a rupture of waste bags. They should provide protection against leakage of fluids. They should be cleaned and disinfected regularly.

- If in-house storage is necessary, the room should be ventilated and surfaces should be disinfected regularly. Waste should be picked up at least once daily.

- If waste bags or containers are stored outdoor, they have to be protected from weather and animals.

- Unauthorized access to collecting space has to be prevented.

\section{References}

1. Kreislaufwirtschaftsgesetz vom 24. Februar 2012 (BGBI. I S. 212), das durch $\S 44$ Absatz 4 des Gesetzes vom 22. Mai 2013 (BGBI. I S. 1324) geändert worden ist.

2. Infektionsschutzgesetz vom 20. Juli 2000 (BGBI. I S. 1045), das durch Artikel 4 Abs. 21 des Gesetzes vom 7. August 2013 (BGBI. I S. 3154) geändert worden ist.

3. Verordnung über die Nachweisführung bei der Entsorgung von Abfällen (Nachweisverordnung - NachwV) vom 20. Oktober 2006 (BGBI. I S. 2298), zuletzt geändert durch Art. 5 Abs. 27 $\mathrm{G}$ zur Neuordnung des Kreislaufwirtschafts- und Abfallrechts v. 24.2.2012 (BGBI. I S. 212).

4. Verordnung über die innerstaatliche und grenzüberschreitende Beförderung gefährlicher Güter auf der Straße, mit Eisenbahnen und auf Binnengewässern (Gefahrgutverordnung Straße, Eisenbahn und Binnenschifffahrt - GGVSEB). BGBI. I Nr. 4 vom 6. Februar 2013.

5. BImSchG 2013: Bundes - Immissionsschutzgesetz in der Fassung der Bekanntmachung vom 17. Mai 2013 (BGBI. I S. 1274), das durch Artikel 1 des Gesetzes vom 2. Juli 2013 (BGBI. I S. 1943) geändert worden ist.

6. 2000/532/EC: Commission Decision of 3 May 2000 replacing Decision 94/3/EC establishing a list of wastes pursuant to Article 1(a) of Council Directive 75/442/EEC on waste and Council Decision 94/904/EC establishing a list of hazardous waste pursuant to Article 1(4) of Council Directive 91/689/EEC on hazardous waste (notified under document numer C (2000) 1147) www.eur-lex.eu/LexUniservLexUniServ.do

7. Vollzugshilfe zur Entsorgung von Abfällen aus Einrichtungen des Gesundheitsdienstes. Mitteilung der Bund Länder Arbeitsgemeinschaft Abfall (LAGA) 18, 2009.

8. Debatin JF, Goyen M, Kirstein A, Eds. Alles grün ....auch im Krankenhaus, Stuttgart, Thieme 2011.

9. Prüss-Ustun A, Emmanuel J, Rushbrook P, et al. Eds. Safe management of wastes from health-care activities, 2nd edn. WHO 2013.

10. Mikloweit U, Hansen D, Ross B, Popp W. Entsorgung in Krankenhaus und Praxis. Umweltmed - Hygiene - Arbeitsmed 2013; 18(4): 187-197.

11. VerpackV 1998: Verordnung über die Vermeidung und Verwertung von Verpackungsabfällen (Verpackungsverordnung - VerpackV) vom 21. August 1998 (BGBI. 1 S. 2379) zuletzt geändert durch Art. 5 Abs. 19 G zur Neuordnung des Kreislaufwirtschafts- und Abfallrechts v. 24.2.2012 (BGBI 1 S. 212).

12. Popp W, Hansen D, Hilgenhöner M, Grandek M, Heinemann A, Blättler T. Waste management in hospitals. Current situation in the state of North Rhine-Westphalia. Bundesgesundheitsbl 2009; 52: 753-763. http://dx.doi.org/10.1007/s00103-009$0877-6$

13. Heinemann A, Diekmann F. Abfallentsorgung - Informationen zur sicheren Entsorgung von Abfällen im Gesundheitsdienst. Hamburg: Berufsgenossenschaft für Gesundheitsdienst und Wohlfahrtspflege 2007.

14. Hansen D, Ross B, Hilgenhöner M, et al. Handling of laundry and garbage in nursing homes. A survey in 22 homes. Bundesgesundheitsbl 2011; 54: 1153-1160. http://dx.doi. org/10.1007/s00103-011-1360-8 